profiles of $1,500 \mathrm{ft}$. in length taken normal to the contact, the mean composition of all samples was found to remain the same. The formation had remained a closed system and there appeared to be no metasomatism ; metamorphic differentiation had, however, occurred along each profile and compositional gradients had been set up.

A general impression left by the discussion on the distribution of minor elements was that most investigations nowadays involve far more analyses than heretofore; this is a healthy development. There is no doubt that a vast amount of fresh and exciting information remains to be unearthed, but real progress will only be achieved by combining quality with quantity.

1 Ahrens, L. H., Pinson, W. H., and Kearns, M. M., Geochim. Cosmochim. Acta, 2, 229 (1952).

'Nockolds, S. R., and Allen, R., Geochim. Cosmochim. Acta, 4, 105 (1953).

sockolds, S. R., and Allen, R., Geochim. Cosmochim. Acta, 5, 245 (1954).

- Ahrens L. H., Nature [174, 644 (1954)]

- Sahama, Th. G., Bull. Comm. geol. Finlande, 136, 15 (1945).

- Shaw, D. M., Geochim. Cosmochim. Acta, 2, 185 (1952).

\section{ANIMAL POPULATIONS AND FORESTRY}

\begin{abstract}
A $\mathrm{T}$ the recent meeting in Oxford, Sections $\mathrm{D}$ A (Zoology) and $\mathrm{K}^{*}$ (Forestry) of the British Association held a combined symposium under the chairmanship of Prof. L. W. Grensted to discuss animal populations with reference to British forestry. Mr. G. H. Thompson, of the Department of Forestry, University of Oxford, opening the symposium with a general introduction, reviewed briefly some of the more important forms of injury caused by animals at different stages in the life of a forest. Insects, rabbits, squirrels, mice and voles often severely damage seed and young trees. In older forests the chief pests are insects, particularly those feeding on foliage. Conifers have a smaller capacity for regenerating lost foliage than broad-leaved trees, yet in Great Britain defoliating insects have so far killed comparatively few conifers. The British fauna includes species, such as the nun moth and pine noctuid, that are important pests of conifers on the Continent of Europe, but which in Britain have so far remained uncommon: the reason for their scarcity is unknown. The pine looper (Bupalus piniarius L.), although usually a common moth, first reached epidemic numbers in 1953 at Cannock Chase, completely defoliating 120 acres of Scots pine and severely attacking a much larger area. A similar attack in 1954 would almost certainly produce heavy tree mortality. Non-lethal degrees of defoliation presumably reduce growth increment, but no data exist.

Trees weakened by drought or defoliation, or unthrifty owing to unsuitable site conditions or old age, are susceptible to attack by insects such as wood-wasps and certain bark-beetles which cannot successfully oviposit in healthy vigorous trees. At Cannock Chase the defoliated pine are entered by $a$ bark-beetle (Myelophilus piniperda L.), the tunnels of which in the cambium girdle and kill trees that might recover if protected from further loss of foliage. It is often hard to decide whether an insect species feeds exclusively on weakened trees, because of the difficulty of defining health.
\end{abstract}

Apart from safeguarding future vigour by choosing tree species suited to the sites to be planted, the forester may attempt to prevent or reduce animal injury by sylvicultural, biological or by chemical means. His choice of methods should be based on ecological knowledge, and in particular of those factors limiting population numbers. In fact, little is known of the population dynamics of even the more important forest pests. The science is new, and population studies are very time-consuming; the collection of data for even a dozen species of insect and three species of mammal is a formidable task. Climate, predators and parasites, and food supply are probably the chief factors influencing animal numbers. Past freedom from epidemics of coniferous defoliators may have been due to the absence of large blocks of forest of an appropriate age-class.

The application of insecticides may be justifiable to save a tree crop otherwise doomed; but, apart from the expense and impermanence of treatment, the biological implications are not fully understood, and the pest may ultimately benefit by destruction of its associated parasites and predators, or resistance to the insecticide may be developed. Forest practice should aim at keeping the injurious animal fauna below the level at which economic damage occurs by biological and sylvicultural methods; and to achieve this objective detailed knowledge is required of the factors affecting animal numbers.

Mr. F. A. Courtier, of the British Forestry Commission, described studies recently initiated to determine a satisfactory method of estimating grey squirrel populations in order that the efficacy of control measures may be assessed. A native of North America, the grey squirrel was first observed in Great Britain in 1828 and has since spread to almost every county. It is most injurious in forests, particularly to broad-leaved trees, girdling and killing stems at ground-level and also destroying leading shoots. Barking usually occurs in late spring or early summer when sap-flow is most active. There are two main breeding periods-DecemberJanuary and May-June. The restricted breeding periods and relatively long time-ten weeks-spent by the young in the drey offer excellent opportunities for control.

Visual counts of adults have not given comparable results under varied woodland conditions. The relationship between the number of the breeding and the sheltering type of drey and the size of the squirrel population is being studied in mature oak woodland.

Courtier referred to estimates of population by the capture-recapture method being undertaken by Monica Shorten in an isolated wood that offers seasonal variation in food; this produces a more settled squirrel population. After intensive trapping, marking and release, the area is cleared of dreys and as many squirrels as possible are killed. Records of marked squirrels shot also provide information concerning their movements.

The squirrel population on a small area in Alice Holt forest is being studied for a period of years. Permanent trapping sites have been established. After pre-baiting for five drys, trapping is conducted for four consecutive days; this procedure is repeated at intervals of six weeks. Trapped squirrels are marked and released after recording sex, weight, breeding condition, injuries and moult-stage. The squirrels show little fear of the traps and appear not 
to travel far, almost all recaptures being in the original traps, Twelve nesting-boxes have recently been erected to provide information on young squirrels and their ultimate dispersal.

Mr. H. N. Southern, of the Bureau of Animal Population, University of Oxford, dealt with fundamental population studies of two of the commonest deciduous woodland rodents, the wood mouse (Apodemus sylvaticus L.) and the bank vole (Clethrionomys glareolus Schreb.). These two species probably play an important part in preventing forest regeneration, but little is known about the control of their numbers. The first step in studying this problem is to know what numbers are present and how many are born and die every year. The best available method is live-trapping. A proportion of the population is caught, marked with numbered leg-rings and released. Iater, another trap sample is taken to determine the proportion of marked to unmarked animals, and so the number present at the original marking can be calculated. An extension of this method from a series of trappings also gives information on the numbers coming into and leaving the population during each interval. The statistical problems involved in this kind of calculation have been recently discussed by Chitty and Leslie, and under optimum conditions estimates should be accurate to within 10 per cent. However, serious errors may be introduced by the marked animals entering the traps more readily than the unmarked ones. This complication is still being studied.

Preliminary results from continuous trappings on 250 acres of woodland between 1948 and 1952 suggest that the trappable population of both rodents varies between 5 and 25 per acre according to season. But there are other more interesting variations. During the first year both species reached a peak in autumn; in the second year wood mice failed to reach an autumn peak; in the third year both species failed to reach an autumn peak; in the final year both species were recovering from this decline in numbers. It is interesting to note that the tawny owls (Strix aluco L.) which were preying on these rodents, and whose population was also being studied, showed repercussions. In the first year they preyed mostly upon wood mice; in the second year they changed to bank voles when the wood mice declined; in the third year-when both prey species were at their lowest ebb-the owls practically failed to rear any young because of food shortage.

These preliminary results illustrate the labour which will be needed to obtain a true idea of the balance of interrelationships between members of an animal community. Only when these fundamental problems are thoroughly understood will it be possible to predict, and perhaps prevent, economic catastrophes instead of resorting to ad hoc measures to palliate damage already done.

Dr. Myles Crooke, of the Forestry Commission, described a survey conducted in Britain during the winter of 1953-54 into the status of the pine looper (Bupalus piniarius) in all the State pine forests considered to be susceptible to attack. The survey was a sequel to the pine looper epidemic at Cannock Chase in 1953. The moth has an annual life-cycle: adults are in flight from May until July and the larvæ feed until October or later before descending into the litter layer to pupate. The survey was extensive in design and was based on counts of number of pupæ found in quadrats one yard square. At low populations the insects are uniformly distributed and a sampling intensity of 0.005 per cent is considered satisfactory. This is achieved by assessing five quadrats in about one out of every ten compartments in a forest. The intensity of sampling is increased when populations are high. For example, at Cannock Chase every compartment of suitable age was sampled, using as many as fifty quadrats per compartment. Four population zones were discernible: (1) defoliation complete: more than 150 pupæ per sq. yd. ; (2) defoliation severe: 80-150 pupæ per sq. yd ; (3) defoliation not serious: 40-80 pupæ per sq. yd.; (4) no apparent defoliation: less than 40 pupæ per sq. yd.

On the Continent of Europe, where intensive sampling over a small area is employed, the endemic population-level is considered not to exceed $0 \cdot 1$ pupæ per square metre: a mean of six or more pupæ per square metre carries the threat of obvious defoliation the following summer. The British survey shows that many forests exhibit considerably higher pupal counts than this. It would seem that either a much higher endemic level can be maintained under British conditions, or that pine looper populations are on the increase and epidemics similar to that at Cannock may be expected elsewhere. No underlying couse, such as recent climatic change, is apparent to support the latter hypothesis.

The normal range of population fluctuations, capacity for increase and limiting factors of the pine looper require investigation. Meanwhile, the survey has proved of immediate value in indicating areas where control measures are necessary.

Prof. G. C. Varley, of the Hope Department of Entomology, University of Oxford, discussed longterm studies, started in 1949, of the winter moth and other species the larvæ of which defoliate oak trees. This research is currently supported by $a$ grant from the Nature Conservancy. In order to assess the effects of climatic factors and of predators and parasites it is necessary to estimate the population densities of the species concerned as frequently as possible and to understand the life-cycles of the commoner parasites and predators. Some forest insects, like the winter moth, are particularly easy to study: they spend the early summer in the larval stage feeding upon the young leaves of oak, where they can be sampled. From these samples some idea of the effects of parasites and predators can be gained. They then spin to the ground on a silken thread and can be intercepted by traps covering a known area. A detailed investigation of this sample provides an estimate of the factors killing full-grown larvæ.

A census is made of the winter moth adults by trapping a sample as they ascend the trees in November or December. The results can be expressed in the form of a table showing the successive causes of mortality and their percentage. The largest percentage destruction takes place between the time of adult emergence and the appearance of the well-grown caterpillars. The percentage of survival of the eggs presumed to be laid on the trees has been found to vary considerably from tree to tree. On trees which open their buds early some 10 per cent of the expected number of caterpillars can be discovered; but on trees which flush late only 2 per cent of the expectation is found. This is partially due to the dispersal of caterpillars when they first enter oak buds. In windy weather they are blown considerable distances on threads of gossamer and can be trapped at a high 
level between the tree tops on sticky traps. The inability of the winter moth to establish itself in trees which open late suggests that it may be possible to choose strains of oak which may be genetically resistant to this form of damage.

Curiously enough, under those trees which open their buds early the heavy caterpillar population suffers proportionately greater destruction when it enters the pupal stage. This may be due to differential attack by predatory animals such as shrews or small rodents in the soil.

At first sight, parasites seem to be relatively unimportant : they kill some 30 per cent at most of the caterpillars of the winter moth. Similar investigations of other caterpillar species have shown approximately the same degree of parasitism. This might be interpreted as an indication that parasites have little effect on caterpillar numbers. However, since many parasites are specific, this explanation would appear to be incorrect. If a specific parasite of an uncommon host is to maintain its numbers it must be extremely efficient at searching for the favoured host. This suggests that the relatively high efficiency of specific parasites may be the basic factor which keeps their hosts to the status of uncommon species, whereas the winter moth and green tortrix, attacked as they are by far less efficient parasites, remain regular pests of great economic importance.

In discussion, Mr. M. V. Laurie, of the Forestry Commission, pointed out that the pine looper has avoided Corsican pine at Cannock Chase. Dr. E. W. Jones, of Oxford, remarked that wood pigeons and squirrels are sometimes the major destroyers of acorns. He also described preferential feeding by mice on acorns from three trees. Analysis showed that the acorns from the preferred tree had the highest sugar and lowest tannin content. Dr. K. R. S. Morris, of the Nature Conservancy, suggested that destruction of carnivores may be largely to blame for upsetting Nature's balance and emphasized that many animals serve a dual purpose : for example, mice distribute seed as well as destroy it.

The chairman, in summing up, said that the papers read had shown that it is the healthy balance in the body corporate which is the fundamental problem.

G. H. THOMPSON

\section{FACTORS CONTROLLING BIOLOGICAL MULTIPLICATION}

$\mathrm{O}^{\mathrm{N}}$ $\mathrm{N}$ September 24 and 25, the Institute of Biology, with the idea that different fields of investigation often gain from a joint discussion of their results and problems, arranged a symposium on "The Numbers of Man and Animols". The symposium was opened by Sir Alexander Carr-Saunders and he stressed the need for caution in applying the results in one field to the problems of another. There was much vigorous discussion between people of dissimilar training; it demonstrated that the warning had been unnecessary or that it had been heeded. Discussion was greatly helped by the circulation of the papers before the meeting. Most authors assumed, and the assumption seemed to be justified, that their papers had been read; they therefore introduced them with only a brief résumé of the main conclusions and then waited for the argument.

Economics and mathematics dominated the first session. Mr. A. T. Peacock discussed "Economic
Theory and the Concept of an Optimum Population". $\mathrm{He}$ doubted whether we could predict accurately enough the consequences of changing the size of a population for it to be wise to take any active steps to promote such a change; he therefore thought the proposals to diminish Britain's population from 50 to 25 million were misguided. $\mathrm{H}_{\Theta}$ also doubted the value of the concept of an optimum population, but not sufficiently emphatically to satisfy Mr. F. Le Gros Clark, who felt that people who are considering the effects of different sizes of market on production often overlook the fact that much of what is produced could be dispensed with without detriment, and perhaps even with advantage, to the community. Several sperkers in the discussion pointed out that even if the concept had reality, the ideal size must depend on whether we are trying to arrange for comfort in peace or safety in war, and that many economic arguments are trimmed to suit the supposed requirements of strategy. The uncertainty of forecasts about human populations was the theme of Prof. E. Grebenik's paper; he said that forecasts are at least consistent in one thing-they all prove wrong. The main reason for this, he said, is the incursion of new factors such as sanitation and contraception, which affect numbers in opposite but not always equal ways. Contraception was the main theme of the discussion, and the readiness with which the governments and women of Japan and India accepted it was contrasted with the official obstruction of the Catholic hierarchy and the Communist Party. The attitude of the latter was epitomized by a quotation from the recent United Nations population congress in Rome : "The government of the U.S.S.R. does not believe in fitting population to resources but in fitting resources to population". The widely different attitude of people in different parts of the world was also shown by Prof. I. Schapera in a paper on the position in the Bechuanaland Protectorate which was presented but not discussed because of the absence of the author. The Kgatla hold that it is unjust and ridiculous that a woman should not have a child as often as is compatible with the welfare of any existing children, and the Protestant ethic, which is officially held by many of them, has undergone some consequent modification. Sir Charles Darwin looked on contraception as a palliative, and did not think that either it or the awareness of the danger would keep world population from pressing alarmingly on world resources.

Mr. J. G. Skellam's paper on "The Mathematical Approach to Population Dynamics" provoked a discussion on the relative merits of mathematics and observation, although the author had said that they work best when working hand-in-hand and that modern computing machinery can cope with problems approaching the complexity of actual experimental, even if not natural, conditions. $\mathrm{He}$ argued that many ecological experiments are foredoomed to failure by the predictable chance of random extinction because the colonies are so small. Mr. M. F. Solomon pointed out that the rigid mathematical formulation of a hypothesis has the merit that it forces attention on to the component parts of the hypothesis and so might reveal methods of testing not apparent from a verbal statement.

In the next session, Dr. D. Lack gave examples of the types of factor that control the density reached by different species of animal, and he showed that generalization from one species to another is hazardous. In wild populations, reproductive rate is 